\title{
PERBUATAN MELAWAN HUKUM OLEH NOTARIS TERHADAP PEMALSUAN AKTA OTENTIK DALAM JUAL BELI TANAH DI KABUPATEN REMBANG (STUDI KASUS PUTUSAN NOMOR 05/Pdt.G/2009/PN.Rbg)
}

\author{
Faizal Indra Nor Cahyo*, Gunarto** \\ * Mahasiswa Program Magister (S2) Kenotariatan Fakultas Hukum UNISSULA, Semarang email: \\ indrafinc@yahoo.com \\ ** Dosen Fakultas Hukum UNISSULA, Semarang
}

\begin{abstract}
In the sale and purchase of land rights of course there are various parties, including Sellers and Buyers. In this case, Seller (RJ) and Purchaser (IS) 1 purchased land on September 26, 2007 with 10 certificates and total purchase value of land object amounting to Rp 2.232.650.000, - (two billion two hundred thirty two million Six hundred fifty thousand rupiah), due on July 31,2008 , which is until the due date the Purchaser (IS) has not been able to repay it. On the other hand, the Notary of MJ who made the Deed of Sale and Purchase Agreement committed a Law Against Act (PMH) by issuing a Sale and Purchase Deed which should not be issued in case of non-payment. With the formulation of the problem studied are: 1 . What are the legal consequences that occur on a Notary who commits an unlawful act against the Deed of Sale and Purchase Land made? 2. How to solve a case against a Notary who committed a Legal Actions (PMH) on the Deed of Sale and Purchase of Land?

Approach method used in this research is normative juridical research supported by empirical juridical, research specification is analytical descriptive, writer use primary data and secondary data to get data related to this research.

Based on the results of this study, based on the Case Court's Decision Number 05 / Pdt.G / 2009 / PN.Rbg, the case investigation between the Seller (RJ) and the Buyer (IS) on the first issue of the formulation of Notary MJ because it was proven to Act Against Law Falsify the information contained in the Deed of Sale and Purchase which is different from the Deed of Sale and Purchase Bond that has been agreed by both parties, then he must finish the Deed of Sale and Purchase Agreement between the RJ and the IS, and automatically does not Occur And in the formulation of the problem Second, the Buyer (IS) who has made a default booking by not automatically paying the purchase price with the binding agreement between himself and the Seller (RJ), he is charged with a 13th Stipikat to Seller (RJ) discount, With the payment already given To Seller (RJ) by Buyer (IS) is irrevocable and automatically becomes the property of Seller (RJ). As well as Buyer (IS) are charged the court fees that have arisen in advance of the trial.

The author's suggestion in this research is for the seller, should be more careful in choosing and revoking the prospective buyer, thus minimizing the undesirable things that will be done by the Buyers so as to disadvantage the Seller, for the buyer, he must have good faith It should always be upheld that there will be no future Seller, for Notary Public, Notary as a public official should have a Neutral attitude toward both parties in the agreement, can be mediator, law-abiding and not doing the Fight Against Act (PMH), by reason No party harmed.
\end{abstract}

Keywords: Sale and Purchase Agreement, Unlawful Actions, Wanprestatie.

\section{PENDAHULUAN}

Di Negara Republik Indonesia hukum merupakan posisi tertinggi dalam pelaksanaan pemerintahan, pengaturan oleh hukum, yang mengatur, memerintah atau berkuasa adalah hukum. Pelaksanaan pemerintahan harus selalu berpegang teguh pada supremasi hukum. Hukum dipandang sebagai alat untuk mengatur segala hubungan antara manusia baik hubungan antara perorangan, antara perorangan dengan kelompok-kelompok, maupun antara individu atau kelompok dengan pemerintah.

Prinsip Indonesia dari negara hukum adalah menjamin kepastian, ketertiban, dan perlindungan hukum yang berintikan kebenaran dan keadilan. 
Perlindungan hukum dalam perkembangan masyarakat salah satunya tercermin dalam hukum pembuktian, yaitu dengan adanya alat bukti yang dapat menentukan dengan jelas hak dan kewajiban seseorang sebagai subjek hukum. Salah satu alat bukti yang dapat dituntut kebenarannya adalah akta otentik yang dibuat oleh pejabat umum. Pejabat umum yang dimaksud adalah Notaris dan Pejabat Pembuat Akta Tanah (PPAT).

Notaris adalah pejabat umum yang diangkat oleh pemerintah berdasarkan surat keputusan Kementrian Hukum dan Hak Asasi Manusia Republik Indonesia. Pasal 1 Ayat (1) Undang-undang Nomor 2 Tahun 2014 Tentang Jabatan Notaris disebutkan, yang dimaksud dengan Notaris adalah pejabat umum yang berwenang untuk membuat akta otentik dan kewenangan lainnya sebagaimana dimaksud dalam Undang-undang ini. Seberapa jauh kewenangan dalam membuat akta otentik ditentukan dalam Pasal 15 Ayat (1) Undang-undang Nomor 2 Tahun 2014 Tentang Jabatan Notaris disebutkan :

"Notaris berwenang membuat akta otentik mengenai semua perbuatan, perjanjian dan ketetapan yang diharuskan oleh peraturan perundang-undangan dan/atau yang dikehendaki oleh yang berkepentingan untuk dinyatakan dalam akta otentik, menjamin kepastian tanggal pembuatan akta, menyimpan akta, memberikan grosse, salinan dan kutipan akta, semuanya itu sepanjang pembuatan akta-akta itu tidak juga ditegaskan atau dikecualikan kepada pejabat lain atau orang lain yang ditetapkan oleh Undangundang".

Berdasarkan kewenangan yang disebutkan diatas pada Pasal 15 Ayat (2) huruf $f$ Undangundang Nomor 2 Tahun 2014 Tentang Jabatan Notaris juga disebutkan Notaris berwenang pula membuat akta yang berkaitan dengan pertanahan. Artinya sebagai seorang Notaris tidak perlu lagi merangkap menjadi Pejabat Pembuat Akta Tanah (PPAT) untuk melaksanakan kewenangan itu seperti yang disebutkan pada Pasal 1 Ayat (1) Peraturan Pemerintah Nomor 24 Tahun 2016 Tentang Perubahan Atas Peraturan Pemerintah Nomor 37 Tahun 1998 Tentang Peraturan Jabatan Pejabat

\footnotetext{
${ }^{1}$ Indonesia legal center publishing, Himpunan Peraturan Perundang-undangan Jabatan Notaris Dan PPAT,(Jakarta : CV.Karya Gemilang), HIm 2.
}

Pembuat Akta Tanah. Pejabat Pembuat Akta Tanah (PPAT) adalah Pejabat Umum yang diberi kewenangan untuk membuat akta otentik mengenai perbuatan hukum tertentu mengenai hak milik atas tanah dan hak milik atas satuan rumah susun. ${ }^{2}$

Perbuatan-perbuatan hukum tertentu yang dimaksudkan diatas adalah perbuatan-perbuatan hukum tertentu yang telah disebutkan secara limitatif dalam Pasal 2 Peraturan tersebut. Pasal 2 Ayat (1) Peraturan Pemerintah Nomor 37 Tahun 1998 Tentang Pejabat Pembuat Akta Tanah menyatakan :

Pejabat Pembuat Akta Tanah bertugas pokok melaksanakan sebgian kegiatan pendaftaran tanah dengan membuat akta sebagai bukti telah dilakukannya perbuatan hukum tertentu mengenai ha katas tanah atau hak milik atas satuan rumah susun, yang akan dijadikan dasar bagi pendaftaran perubahan data pendaftaran tanah yang diakibatkan oleh perbuatan hukum itu.

Pasal 2 Ayat (2) Peraturan pemerintah Nomor 37 Tahun 1998 Tentang Pejabat Pembuat Akta Tanah menyatakan perbuatan hukum sebagaimana dimaksud pada ayat (1) adalah sebagai berikut :

1. Jual Beli;

2. Tukar Menukar;

3. Hibah;

4. Pemasukan Dalam Perseroan (Inbrenk);

5. Pembagian Hak Bersama;

6. Pemberian HGB atau Hak Pakai Atas Tanah Hak Milik;

7. Pemberian Hak Tanggungan;

8. Pemberian Hak Membebankan Hak Tanggungan. ${ }^{3}$

Perbuatan hukum yang turut serta dibuatkan akta otentik oleh Notaris dan PPAT adalah Jual Beli Hak Atas Tanah. Hak atas tanah adalah hak yang memberikan wewenang kepada pihak yang mempunyai tanah untuk menggunakan atau mengambil manfaat dari tanah yang di hakinya. Pemilikan hak atas tanah tersebut dilakukan dengan memperhatikan fungsi sosial hak atas tanah. Peralihan hak atas tanah dapat dilakukan melalui jual beli, tukar menukar, hibah, pemasukan dalam perusahaan dan perbuatan hukum, pemindahan hak lainnya.

\footnotetext{
${ }^{2}$ Ibid, HIm 200.

${ }^{3}$ Ibid, HIm 201.
} 
Pada kasus perkara perdata yang penulis analisis ini kewenangan Notaris membuatkan akta otentik adalah berupa akta perjanjian pengikatan jual beli tanah. Dalam pembuatan Perjanjian Pengikatan Jual Beli maupun Akta Jual Beli Tanah, Notaris dan PPAT dapat melakukan suatu kelalaian baik yang disengaja maupun yang tidak disengaja dengan turut sertanya salah satu atau beberapa pihak yang mempunyai itikad tidak baik bersama-sama dengan Notaris dan PPAT, hal yang dimaksudkan adalah bahwa Notaris PPAT juga dapat melakukan perbuatan melawan hukum. Hal inilah yang akan penulis angkat dalam penelitian ini.

Berdasarkan paparan dalam latar belakang di atas, beberapa permasalahan pokok yang diteliti adalah sebagai berikut : Bagaimana akibat hukum yang terjadi pada Notaris yang melakukan perbuatan melawan hukum terhadap Akta Jual Beli Tanah yang dibuatnya? Bagaimana penyelesaian kasus terhadap Notaris yang melakukan perbuatan melawan hukum (PMH) pada pembuatan Akta Jual Beli Tanah?

\section{METODE PENELITIAN}

Dalam penelitian ini penulis menggunakan metode penelitian yuridis empiris, yaitu penelitian dengan studi kepustakaan dengan ditunjang studi lapangan berupa penelitian secara langsung. Penelitian ini menggunakan pendekatan sistematis (sistematic approach) yang memperhatikan keterkaitan antara peraturan perundang-undangan yang mengatur mengenai upaya penyelesaian sengketa dalam hal jual beli hak atas tanah yang secara efektif digunakan sebagai perlindungan hukum kepada para pihaknya apabila terjadi suatu kasus atau sengketa dala proses jual beli ha katas tanah ini.

Spesifikasi penelitian ini adalah deskriptif analitis, pengumpulan data dalam penelitian ini dilakukan dengan wawancara kepada praktisi untuk data primer dan menggunakan teknik studi kepustakaan untuk memperoleh data sekunder. Penelitian data sekunder yang berupa bahan hukum primer dan bahan hukum sekunder maupun bahan hukum tersier yang berkaitan dengan pokok permasalahan dalam penelitian ini dilakukan melalui studi kepustakaan dilengkapi dengan wawancara sebagai data pendukung.
Hasil dari wawancara dan studi pustaka sebagai data primer dan sekunder yang telah diperoleh, disusun secara sistematis sesuai dengan masalah yang akan dibahas dalam penelitian. Data yang telah tersusun selanjutnya akan dilakukan analisa menggunakan analisa interpretasi sistemis atau logis, yang mendasarkan pemikiran bahwa terjadinya suatu permasalahan tidak terlepas dari peraturan perundang-undangan yang mengaturnya, tidak dapat dipungkiri bahwa peraturan perundang-undangan inilah yang dapat melindungi para pihak apabila terjadi suatu sengketa pada jual beli ha katas tanah dikemudian hari.

\section{HASIL PENELITIAN DAN PEMBAHASAN}

\section{Akibat Hukum Yang Terjadi Pada Notaris Yang Melakukan Perbuatan Melawan Hukum}

Dalam kasus ini, pada tanggal 26 September 2007 telah terjadi jual beli hak atas tanah diantaranya dengan 10 sertipikat atas nama RJ dan 3 sertipikat atas nama MS (ayah kandung $\mathrm{RJ}$ ) dengan pemberian Surat Kuasa Menjual oeh MS kepada JS (ibu kandung RJ), yang kesemuanya merupakan sertipikat hak milik atas tanah dengan nilai jual beli sebesar Rp 2.232.650.000,- (dua milyar dua ratus tigapuluh dua juta enam ratus lima puluh ribu rupiah), yang mana dengan kesepakatan antara penjual dan pembeli tersebut dengan bersama-sama kedua pihak datang ke kantor Notaris MJ untuk dibuatkan Perjanjian Pengikatan Jual Beli No. 41 / 2007 dengan kesepakatan perincian pembayaran melalui beberapa tahap dengan terlebih dahulu dibayarkan uang muka sebesar Rp 182.650.000,(seratus delapan puluh dua juta enam ratus lima puluh ribu rupiah) dan jatuh tempo waktu pembayaran tanggal 31 Juli 2008. Namun pada saat waktu jatuh tempo berakhir, IS selaku pembeli belum dapat melunasi sisa pembayaran dengan nilai sebesar Rp 540.650.000,- (lima ratus empat puluh juta enam ratus lima puluh ribu rupiah). Dengan ini RJ bersama-sama dengan JS selaku pihak penjual datang ke kantor Notaris MJ untuk meminta Salinan dari perjanjian pengikatan jual beli tersebut. Namun setelah RJ mendapatkan salinan dari PJB tersebut, penjual mengetahui bahwa telah dibuatnya Akta Jual Beli baru yang tidak sesuai dengan Perjanjian 
Pengikatan Jual Beli antara RJ dengan IS, sebagai sarana untuk melakukan proses balik nama ke 13 (tiga belas) sertipikat tanah tersebut menjadi nama Imam Sudjono, Sumini dan Nuryati bahwa tindakan tersebut kesemuanya tanpa persetujuan dari pihak $\mathrm{RJ}$, yang mana seharusnya Akta Jual Beli tersebut tidak boleh diterbitkan oleh Notaris sebelum adanya pelunasan serta kesepakatan antara para pihak penjual dan pembeli sesuai dengan apa yang telah tertulis dalam perjanjian pengikatan jual beli. Adanya itikad tidak baik yang ditunjukkan Notaris salah satunya adalah pengakuan dari $\mathrm{RJ}$ yang telah diminta untuk menandatangani 13 blanko kosong untuk kemudian disimpan kembali oleh Notaris tanpa adanya alasan yang konkrit sebelum terbitnya Akta Jual Beli, yang kemudian digunakan untuk melakukan balik nama sertifikat hak milik atas nama pihak pembeli yaitu IS dari pihak penjual selaku pemilik tanah yaitu RJ.

Analisis dari kasus putusan perkara perdata yang diteliti oleh penulis yaitu dikaitkan dengan beberapa syarat sahnya perjanjian yaitu antara lain asas-asas hukum perjanjian dan syarat sahnya perjanjian itu sendiri dan analisis tentang perbuatan melawan hukum serta pemalsuan keterangan yang telah secara sah dapat dibuktikan dimuka pengadilan. Istilah perbuatan melawan hukum itu memiliki ruang lingkup yang lebih luas dibandingkan dengan perbuatan pidana. Perbuatan melawan hukum tidak hanya mencakup perbuatan yang bertentangan dengan Undang-undang pidana saja tapi juga jika perbuatan tersebut bertentangan dengan Undang-undang lainnya dan bahkan dengan ketentuan-ketentuan hukum yang tidak tertulis. Ketentuan perundang-undangan dari perbuatan melawan hukum bertujuan untuk melindungi dan memberikan ganti rugi pada pihak yang dirugikan. ${ }^{4}$ Perbuatan melawan hukum sendiri adalah sebuah perbuatan melukai (injury) dari pada pelanggaran terhadap kontrak (breach of contract). Maka yang dimaksud dengan perbuatan melanggar hukum adalah perbuatan yang melawan hukum yang dilakukan oleh seseorang yang karena salahnya telah menimbulkan kerugian bagi orang lain. Dalam ilmu hukum dikenal dalam 3 kategori dari perbuatan

\footnotetext{
${ }^{4}$ Rachmat Setiawan, Tinjauan Elementer Perbuatan Melawan Hukum, (Bandung:Alumni 1982), HIm. 15.
}

melawan hukum, yaitu perbuatan melawan hukum karena kesengajaan, perbuatan melawan hukum tanpa kesalahan (tanpa unsur kesengajaan maupun kelalaian) dan perbuatan melawan hukum karena kelalaian. ${ }^{5}$

Sehingga begitu banyak cacat yang terdapat pada perjanjian jual beli antara RJ dan IS ini, yaitu dimulai dari adanya unsur perbuatan melawan hukum yang dilakukan oleh Notaris MJ dan Pihak Kedua (IS) yaitu berupa pemalsuan keterangan, dan tidak dapat terpenuhinya semua asas-asas perjanjian serta tidak terpenuhi pula beberapa syarat sahnya perjanjian. Sehingga perjanjian jual beli antara RJ dan IS ini batal demi hukum atau dari semula telah dianggap tidak pernah terjadi perjanjian. Sehingga berakhir dengan Putusan pengadilan yang memutus Notaris MJ bersama dengan Pihak Kedua (IS) harus membatalkan Akta Perjanjian Pengikatan Jual Beli Nomor 41 tanggal 26 September 2007 dan menghukum pula kepada Notaris MJ untuk menghapus dari daftar minuta yang ada.

\section{Penyelesaian Kasus Notaris Yang Melakukan Perbuatan Melawan Hukum.}

Dengan dibuatnya akta otentik dihadapan Notaris MJ maka seharusnyalah timbul hak dan kewajiban yang secara otomatis melekat pada diri masing-masing pihak, yaitu pihak penjual (RJ) berkewajiban menyerahkan objek jual belinya, dan pihak pembeli (IS) berkewajiban menyerahkan sejumlah uang yang menjadi nilai dari jual beli tersebut, dengan begitu kedua belah pihak tidak akan terlibat dalam suatu masalah yang akhirnya merugikan diri mereka masing-masing. Seperti halnya yang dilakukan oleh IS sebagai pembeli yang tidak melakukan pelunasan sampai dengan batas jatuh tempo yang telah ditentukan yaitu pada tanggal 31 Juli 2008, dengan sisa kekurangan sebesar Rp 540.650.000,- (lima ratus empat puluh juta enam ratus lima puluh ribu rupiah). Maka secara otomatis Pihak IS dapat dikatakan telah melakukan wanprestasi. Padahal telah jelas tertuang dalam isi Pasal Akta Perjanjian Pengikatan Jual Beli bahwa apabila Pihak Pertama (RJ) terhitung sejak tanggal

\footnotetext{
${ }^{5}$ Munir Fuady, Profesi Mulia (Etika Profesi Hukum bagi Hakim, Jaksa, Advokat, Notaris, Kurator, dan Pengurus), Bandung:PT Citra Aditya Bhakti, 2005, HIm. 3.
} 
31 Juli 2008 ingkar janji tidak jadi menjual tanah kepada Pihak Kedua (IS) maka Pihak Pertama (RJ) harus membayar denda Rp 5.000.000,- (Lima Juta Rupiah) untuk tiap-tiap hari keterlambatan hingga berturut-turut hingga 7 (tujuh) hari maka pihak pertama harus mengembalikan semua harga transaksi Jual Beli dengan sanksi segala biaya-biaya yang telah dikeluarkan harus dikembalikan pada Pihak Kedua (IS) / Pembeli 10 kali lipat dari uang yang diterimanya. Sebaliknya apabila pihak kedua tidak membayar sisa harga terhitung sejak tangal 31 Juli 2008, maka Pihak Kedua (IS) harus membayar denda sebesar Rp 5.000.000,- (lima juta rupiah) untuk tiap-tiap hari keterlambatan hingga berturutturut sampai 7 hari maka seluruh uang yang telah dibayarkan kepada pihak pertama hangus (pihak pertama tidak mengembalikan uang yang telah dibayarkan).

Apabila Pihak Kedua (IS) / pembeli tidak membayar sisa harganya, maka Akta Jual Beli tertanggal 28-09-2007 Nomor 1026/KRG/2007 sertipikat hak milik nomor 58 yang terletak di Kelurahan Sumbersari, Kecamatan Kragan, Kabupaten Rembang seluas $10.050 \mathrm{M}^{2}$ yang telah dibalik nama keatas nama Pihak Kedua (IS) dinyatakan batal demi hukum dan harus dikembalikan keatas nama Pihak Pertama (RJ), semua biaya yang timbul menjadi tanggung jawab Pihak Kedua (IS) dan untuk itu sertipikat tersebut harus tetap disimpan oleh Notaris, yang berdasarkan Berita Acara Pembetulan Akta Perjanjian Pengikatan Jual Beli tertangal 15 September 2009 yang dibuat dan ditandatangani $\mathrm{MJ}$, klausul tersebut dibetulkan hinga tertulis "apabila pihak kedua atau pembeli tidak membayar sisa haragnya maka Perjanjian Pengikatan Jual Beli ini menjadi batal dan ketiga belas Sertipikat Hak Milik tersebut pada pasal 1 harus tetap disimpan oleh Notaris MJ.

Dalam Putusan Pengadilan dalam Perkara Perdata dengan Nomor 05/Pdt.G/2009/PN.Rbg, akhir dari Kasus yang telah melibatkan Pihak Pertama (RJ) dan Pihak Kedua (IS) yang melakukan wanprestasi, serta Notaris MJ yaitu:

Pihak Kedua (IS) yang telah melakukan wanprestasi, dituntut untuk turut serta menyetujui pembatalan Akta Perjanjian Pengikatan Jual Beli tanggal 26 September 2007 Nomor 41 yang telah dibuat oleh Notaris MJ karena Akta Perjanjian Pengikatan Jual beli tersebut cacat demi hukum, mengembalikan ketiga belas (13) Sertipikat Hak Milik atas nama para Pihak Pertama (RJ), serta membayar biaya-biaya perkara pengadilan sebesar $\mathrm{Rp}$ 1.442.800 (satu juta empat ratus empat puluh dua ribu delapan ratus rupiah). Dan uang yang telah dibayarkan oleh Pihak Kedua (IS) hangus dan Pihak Pertama (RJ) tidak mengembalikan uang yang telah dibayarkan.

\section{PENUTUP}

\section{Simpulan}

1. Akibat Hukum Yang Terjadi Pada Notaris Yang Melakukan Perbuatan Melawan Hukum

Begitu banyak cacat yang terdapat pada perjanjian jual beli antara RJ dan IS ini, yaitu dimulai dari adanya unsur perbuatan melawan hukum yang dilakukan oleh Notaris MJ dan Pihak Kedua (IS) yaitu berupa pemalsuan keterangan, dan tidak dapat terpenuhinya semua asas-asas perjanjian serta tidak terpenuhi pula beberapa syarat sahnya perjanjian. Sehingga perjanjian jual beli antara RJ dan IS ini batal demi hukum atau dari semula telah dianggap tidak pernah terjadi perjanjian. Sehingga berakhir dengan Putusan pengadilan yang memutus Notaris MJ bersama dengan Pihak Kedua (IS) harus membatalkan Akta Perjanjian Pengikatan Jual Beli Nomor 41 tanggal 26 September 2007 dan menghukum pula kepada Notaris MJ untuk menghapus dari daftar minuta yang ada.

2. Penyelesaian Kasus Notaris Yang Melakukan Perbuatan Melawan Hukum.

Perjanjian itu merupakan suatu peristiwa dimana seseorang berjanji kepada orang lain atau dimana dua orang itu saling berjanji untuk melaksanakan sesuatu hal. Perjanjian itu sendiri menerbitkan suatu perikatan antara dua orang yang membuatnya baik itu bersifat lisan maupun tertulis. Berdasarkan Pasal 1338 Ayat (1) Kitab Undang-undang Hukum Perdata yang berbunyi "Semua perjanjian yang dibuat secara sah, berlaku sebagai Undang-undang bagi mereka yang membuatnya".6

Dalam Putusan Pengadilan dalam Perkara Perdata dengan Nomor 05/Pdt.G/2009/PN.Rbg,

\footnotetext{
${ }^{6}$ Putusan Pengadilan dalam Perkara Perdata dengan Nomor 05/Pdt.G/2009/PN.Rbg, hlm. 53
} 
akhir dari Kasus yang telah melibatkan Pihak Pertama (RJ) dan Pihak Kedua (IS) yang melakukan wanprestasi, serta Notaris MJ yaitu:

Pihak Kedua (IS) yang telah melakukan wanprestasi, dituntut untuk turut serta menyetujui pembatalan Akta Perjanjian Pengikatan Jual Beli tanggal 26 September 2007 Nomor 41 yang telah dibuat oleh Notaris MJ karena Akta Perjanjian Pengikatan Jual beli tersebut cacat demi hukum, mengembalikan ketiga belas (13) Sertipikat Hak Milik atas nama para Pihak Pertama (RJ), serta membayar biayabiaya perkara pengadilan sebesar Rp 1.442 .800 (satu juta empat ratus empat puluh dua ribu delapan ratus rupiah). Dan uang yang telah dibayarkan oleh Pihak Kedua (IS) hangus dan Pihak Pertama (RJ) tidak mengembalikan uang yang telah dibayarkan.

\section{Saran}

1. Bagi Penjual : Dalam melakukan perjanjian jual beli Pihak Penjual seharusnya lebih berhati-hati dengan mengetahui latar belakang calon Pembelinya, terlebih jika nilai objek jual beli tersebut memiliki harga yang sangat tinggi, tentunya agar lebih dapat diketahui apabila suatu saat terjadi kasus-kasus yang dapat menghambat atau bahkan membatalkan perjanjian jual beli tersebut, sehingga Pihak Penjual tidak menanggung kerugian akibat perbuatan (wanprestasi) yang dilakukan oleh Pembeli.

2. Bagi Pembeli : Dalam melakukan perjanjian jual beli wajib didasari dengan itikad baik, baik oleh Penjual maupun Pembeli. Terlebih yang lebih sering mempunyai itikad tidak baik adalah Pembeli yakni dengan melakukan wanprestasi. Seharusnyalah apabila ia sebagai pembeli telah berjanji mengikatkan dirinya untuk melakukan jual beli, maka ia wajib menepatinya hingga jual beli tersebut berakhir, agar tidak ada pihak-pihak yang merasa dirugikan atas itikad tidak baik yang ditimbulkan oleh Pembeli tersebut.

3. Bagi Notaris : Notaris sebagai pejabat umum yang menjadi jembatan dalam memformulasikan keinginan pihak penjual dan pembeli tersebut seharusnya mempunyai sikap netral terhadap keduanya, dapat menjadi penengah apabila salah satu pihak telah melakukan perbuatan yang melenceng dari isi perjanjian yang telah dibuatnya. Sehingga Notaris tidak akan melakukan perbuatan-perbuatan yang dilarang didalam kode etik jabatannya dengan bersikap tidak netral dan melakukan perbuatan melawan hukum sehingga dapat merugikan salah satu pihak didalam perjanjian tersebut.

\section{DAFTAR PUSTAKA}

Fuady Munir, 2005, Profesi Mulia (Etika Profesi Hukum bagi Hakim, Jaksa, Advokat, Notaris, Kurator, dan Pengurus), PT Citra Aditya Bhakti, Bandung.

Indonesia legal center publishing, Himpunan Peraturan Perundang-undangan Jabatan Notaris Dan PPAT, CV.Karya Gemilang, Jakarta

Setiawan, Rachmat, 1982, Tinjauan Elementer Perbuatan Melawan Hukum, Alumni, Bandung.

Putusan Pengadilan dalam Perkara Perdata dengan Nomor 05/Pdt.G/2009/PN.Rbg 